$\frac{12}{9} / 2^{5}-958.50$

UCRL-ID-121182

Waste Acid Recycling via Diffusion Dialysis

(4)

\author{
C. Steffani
}

May 26, 1995

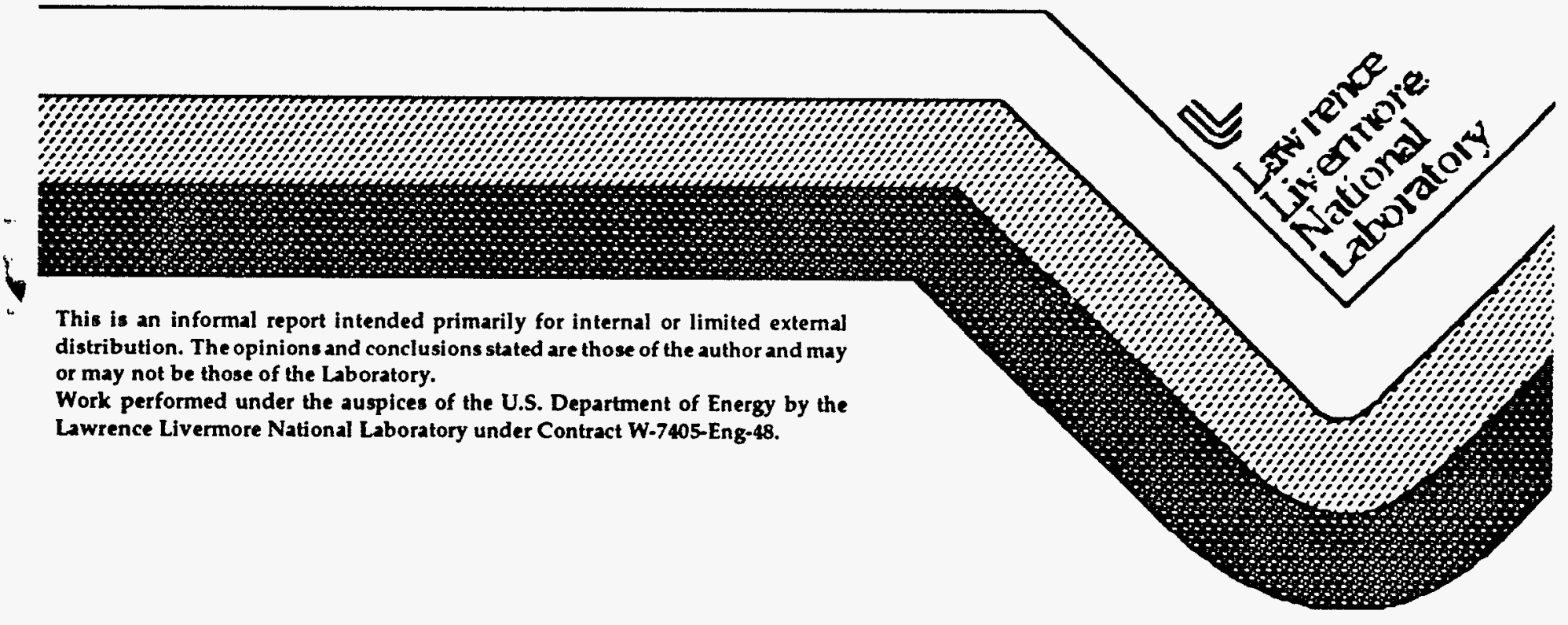


This document was prepared as an account of work sponsored by an agency of the United States Government. Neither the United States Government nor the University of California nor any of their employees, makes any warranty, express or implied, or assumes any legal liability or responsibility for the accuracy, completeness, or usefulness of any information, apparatus, product, or process disclosed, or represents that its use would not infringe privately owned rights. Reference herein to any specific commercial product, process, or service by trade name, trademark, manufacturer, or otherwise, does not necessarily constitute or imply its endorsement, recommendation, or favoring by the United States Covernment or the University of California. The views and opinions of authors expressed herein do not necessarily state or reflect those of the United States Covernment or the University of California, and shall not be used for advertising or product endorsement purposes.

This report has been reproduced directly from the best available copy.

Available to DOE and DOE contractors from the

Office of Scientific and Technical Information

P.O. Box 62, Oak Ridge, TN 37831

Prices available from (615) 576-8401, FTS 626-8401

Available to the public from the

National Technical Information Service

U.S. Department of Commerce

5285 Port Royal Rd.,

Springfield, VA 22161 


\title{
Waste Acid Recycling via Diffusion Dialysis*
}

\author{
Chris Steffani \\ Manufacturing and Materials Engineering Division \\ Lawrence Livermore National Laboratory
}

Inorganic acids are commonly used in surface finishing shops to remove surface scales, produce bright surfaces, strip unwanted metals and/or coatings, and prepare metal surfaces to receive other coatings. These acids can also be used as the electrolyte for coatings produced by electrolytic oxidation such as anodizing. Sooner or later the acids become unusable due to contamination with metals, the conversion of the hydrogen ion into hydrogen gas, or they become weakened by either dragout or dilution.

The historic way of dealing with these spent acids is to either to dilute or neutralize them and pass them into the rinse water stream or precipitate the metal component as a hydroxide filter cake and send the metal free liquid to the POTW. The problems with these methods are that a new bath must be made up when the old is discarded and the cost of treatment chemicals and equipment is high. Because most acids become contaminated with metals before the acid value is completely exhausted, many times more acid is wasted during dilution than is used for precipitation of the metal.

Recycling of the spent acid has been limited to use as an alkaline neutralizing chemical during waste treatment. Diffusion dialysis equipment has provided a way to recover the usable acid and allow separation of the metal component for recovery and sale to refineries. This technique has been made possible by the invention of membranes that are strong enough to withstand low $\mathrm{pH}$ solutions and have long life in an industrial environment.

The process places the acid on one side of a semi-permeable membrane and de-ionized water on the other. The exchange of ions happens due to the desire of the two liquids to come to equilibrium. The membrane prevents the movement of the metal ions and only allows the diffusion of the hydrogen ion. If the contact time is set at the right interval, much of the acid crosses the membrane while the metals remain behind. The technology is similar to that used by kidney dialysis patients when removing waste products from their blood stream.

The basic equipment is fairly simple: a semi-permeable membrane, two metering pumps, de-ionized water, and some waste acid. After setting up the dialysis equipment, the operator sets the retention time to a pre-selected value to insure maximum acid recovery or metal rejection depending on the stream being recovered. The low acid/high metal reject can then be sent to a electrowinning unit, and the recovered acid can be returned to the processing area.

* This work was performed under the auspices of the U.S. Department of Energy by Lawrence Livermore National Laboratory under contract No. W-7405-Eng-48. 


\section{DISCLAIMER}

Portions of this document may be illegible in electronic image products. Images are produced from the best available original document. 
Various acid solutions and mixtures of acids have been recovered at LLNL using this technology. One drawback is the time involved for recovery of large volumes. The recovery rate is dependent on the size of the membrane diffusion area. A 50 cell pair stack, which retails for about $\$ 9,000$, will recovery about 10 gallon per day (GPD). Another drawback is the recovery of mixed acids in which one of the acids is monoprotic such as $\mathrm{HCl}$ and the other is diprotic such as $\mathrm{H}_{2} \mathrm{SO}_{4}$. The difference in the number of protons causes the rejection of some of the diprotic acid. In this case, a second recovery run may have to be performed in order to recover more of the diprotic acid. Another thing to be aware of is the doubling in size of the volume of liquid that is being recovered. The volume of deionized water that receives the waste acid will have to be contended with, but if electrowinning is done, followed by evaporation this should not present any problems. The following is a compilation of recovery values from using the equipment with assorted waste acid streams.

Test 1 was a nitric acid solution that was used to strip copper from aluminum and SST electroforming mandrels. The stripping rate had diminished even though the available acid was still high. The following values represent the acid and metal values before and after the recycling process:

(start)

$4.9 \mathrm{~N}$ nitric acid $60 \mathrm{gm} / 1$ copper metal (finish)

$3.9 \mathrm{~N}$ Nitric acid $(79.5 \%$ recovery) $7.2 \mathrm{gm} / 1$ copper metal ( $88 \%$ rejection)

The reject solution (130 gallons) was evaporated and re-concentrated and reprocessed through the system again. After all processing was complete, the metal (60 lbs) was recovered by electrowinning and the spent liquor was recovered by vacuum distillation. A small amount of waste was generated from the mixing of the liquor with the accumulation in the vacuum distillation vessel.

Test 2 was conducted on a solution used to descale steel and deoxidize copper. The available acid was quite high but the copper in the solution was immersion plating on the steel, causing problems with the pre-cleaning process. an electrowinning process was attempted to remove the copper but was not very successful because of the large cathodes area required to reduce the copper to any acceptable level. Also, some acid was destroyed because of the inefficiency of the process. The following values represent the acid and metal values before and after the recycling process:

$$
\text { (start) }
$$

9.4 $\mathrm{N}$ muriatic acid $10 \mathrm{gm} / 1$ copper metal $14 \mathrm{gm} / \mathrm{iron}$ metal (finish)

$7.1 \mathrm{~N}$ muriatic acid ( $75.5 \%$ recovery)

$1.1 \mathrm{gm} / /$ copper metal ( $89 \%$ rejection)

$3.1 \mathrm{gm} / \mathrm{l}$ iron metal $(77.8 \%$ rejection) 
The process generated 110 gallons of low acid medium metal concentration which was vacuum distilled to re-concentrate it. It was run through the system again and another $75 \%$ of the acid was recovered. At this point the waste volume was only 25 gallons and it was added to the common waste from the vacuum distillation unit and trucked off-site for treatment and disposal. The electrowinning of this concentrated metal was partially successful but the small volume made it inefficient to recover from this solution. If a larger waste stream had been available, then it would have been economical to remove the metal and send it to a refiner.

Test 3 was done on a spent electrolytic activation solution. The solution again had a very high acid value but work processed through it started to local etch and pit because of contamination from excess metals. The following values represent the acid and metal values before and after the recycling process:

(start)

$6.5 \mathrm{~N}$ sulfuric acid

$24 \mathrm{gm} / \mathrm{l}$ nickel metal

$14 \mathrm{gm} / 1$ iron metal

$9 \mathrm{gm} / \mathrm{chromium}$ metal (finish)

$5.8 \mathrm{~N}$ sulfuric acid ( $89.2 \%$ recovery)

$2.6 \mathrm{gm} / \mathrm{nickel}$ metal (91\% rejection)

$3.1 \mathrm{gm} / 1$ iron metal ( $78 \%$ rejection)

$2.2 \mathrm{gm} / \mathrm{chromium}$ metal ( $76 \%$ rejection)

After recovery and adjustment to the original operating concentration, the solution again operated as it did when it was new. The waste products were concentrated by vacuum distillation and sent off as waste (18 gallons).

Test 4 was conducted on a waste type II sulfuric anodizing solution. The operating concentration of the solution is too dilute to allow any dialysis so the solution was distilled to $5 \mathrm{~N}$ from its operating concentration of 1.8 normal. The dissolved aluminum was also concentrated and some of it was removed from the bottom of the distillation vessel prior to acid recovery. The following values represent the acid and metal values before and after the recycling process:

(start)

$5.1 \mathrm{~N}$ sulfuric acid $182 \mathrm{gm} / \mathrm{l}$ aluminum metal

$7 \mathrm{gm} / \mathrm{l}$ copper metal (finish)

$4.6 \mathrm{~N}$ sulfuric acid $(90.1 \%$ recovery) $12.1 \mathrm{gm} / 1$ aluminum metal (94\% rejection) $.8 \mathrm{gm} / 1$ copper metal (89\% rejection)

The recovered acid was diluted with DI water and sent to replenish the anodizing bath. After dilution the aluminum content was $2.6 \mathrm{gm} / 1$ and the copper was only 230 PPM. The waste liquor was added to the common distillation tank and the total waste was estimated at 10 gallons of liquid and $10 \mathrm{lbs}$ of solid waste. 
Several bright dipping solution were tested with the diffusion dialysis equipment but because of the mix of mono and diprotic acids a steady recovery rate was hard to estimate. By using a two step process; the 1st to recover the monoprotic acid, and a 2nd step after distillation to reject the water from the diffusion process, about $55 \%$ of the bright dip was recovered. Because of problems mixing the solution back into the appropriate concentrations, more work is needed to perfect this type of recovery.

\section{Conclusions:}

Diffusion dialysis a very cost effective way of recovering and separating acid waste streams. Looking at a cost based analysis brings up the following examples. This includes the cost of the original bath, the hydroxide used to neutralize the acid and precipitate the metal, the disposal of the sludge, and the cost to purchase the new acid for the next bath. It does not include the cost of the labor, polymer, clarifier, settling tank, and sludge dryer:

$\mathrm{HCl} \$ 0.80 /$ gallon $\times 70$ gallons $=\$ 56.00$

$\mathrm{NaOH}: \$ 0.68 /$ gallon $x 23$ gallons $=\$ 15.46$

Disposal $\$ 1.85 / \mathrm{lb} \times 43 \mathrm{lbs}=\$ 80.25$

$\mathrm{HCl} \$ 0.80 /$ gallon $\times 70$ gallons $=\$ 56.00$

TOTAL $=\$ 207.71$

This shows the cost of the dialysis recovery. It too includes the cost of the original bath but the cost of the new solution and disposal of the waste is about $10 \%$ that of the treatment process. It does not include the cost of the recycling equipment, but it is also much less that of a treatment system and does not require the manpower either. It does also not include the resale value of any reclaimed metal but that is offset by the cost of electricity to win it back from the liquid.

$\mathrm{HCl} \$ 0.80 /$ gallon $\times 70$ gallons $=\$ 56.00$

Disposal $\$ 1.85 / \mathrm{lb} \times 4 \mathrm{lbs}=\$ 7.40$

$\mathrm{HCl} \$ 0.80 /$ gallon $\times 10$ gallons $=\$ 8.00$ TOTAL $=\$ 71.40$

savings of $\$ 136.31$

Recovery parameters are dependent upon acid concentration, TDS, DI water quality, and membrane exposure times. Membrane exposure was optimized for maximum metal rejection. These results are only meant to be representative of what your recovery might be. To determine your actual recovery and cost you should submit a sample of your spent acid to the manufacturer for testing. 